\title{
Sosyal Medya Kullanımı İle Kendini Gizleme ve Yaşam Doyumu Arasında Bir Bağlantı Var mı?
}

\section{Is There a Connection between Social Media Use and Self-Concealment and Life Satisfaction?}

\author{
Prof. Dr. Şükrü BALCI ${ }^{1}$, Dr. Öğr. Üyesi Abdulkadir GÖLCÜ ${ }^{2}$, Doktora Öğrencisi \\ Ayşe Arsal GÖLCÜ ${ }^{3}$
}

\begin{abstract}
Özet
Toplumsal yaşamda insanları sosyal medya kullanımına yönelten birçok neden bulunmaktadır. Bu iletişim ortamında kullanıcı, kendi kişisel sayfası üzerinden ilgilerini ortaya koyabilmekte, e-maile benzeyen mesaj bölümü gibi çeşitli uygulamalar sayesinde karşıllıklı iletişim kurabilmekte, enformasyon elde etmekte, arkadaşlıklar kurabilmekte, insanların iletişim bilgisine ulaşabilmekte, fotoğraf ve görüntülerini diğer insanlarla paylaşabilmekte ya da kişisel bilgileri hakkında insanlara veri sunabilmektedir. Sosyal medya farklı kimliklerle kullanıcıların kendilerini ifade edebildikleri bir mecradır. Öyle ki sosyal görünürlük kaygısı yaşayan ve kendini gizleme duygusuna sahip insanlar için, sosyal medya çeşitli imkânlar sunmaktadır. Sosyal medyanın sağlamış olduğu bu olumlu ya da olumsuz olanak, aynı zamanda kullanıcıların yaşam doyumları ile ilişkilendirilmeye başlanmıştır. İște bu araştırma üniversite öğrencileri örneğinde, gençlerin sosyal medya kullanım örüntüleri ile kendini gizleme ve yaşam doyumu arasındaki ilişkiyi ortaya koymak amacıyla yürütülmüştür. Saha araştırması yöntemi ile 333 katılımcıdan veriler toplanmıștır. Araştırma sonucunda sosyal medya kullanım süresi ile kendini gizleme ve yaşam doyumu arasında bir ilişki tespit edilememiştir. Kendini gizleme yönündeki eğilimler, sosyal medyada farklı isimle hesap açma ve kendini farklı tanıtma ya da yansıtma isteğini artırmaktadır. Yine sosyal medyada farklı isimle hesap açmayanların yaşam doyum düzeyleri daha yüksektir.
\end{abstract}

Anahtar Kelimeler: Sosyal Medya, Kendini Gizleme, Yaşam Doyumu, Saha Araştırması

Makale Türü: Araştırma makalesi

\begin{abstract}
There are many reasons to lead people to use social media in social life. In this communication environment, the user can display his / her personal information via his / her own personal page and can communicate with each other through various applications such as a message section resembling an e-mail, acquire information, develop friendships, access people's contact information, share photographs and images with other people; it can present data to people. Social media is a medium in which users can express themselves with different identities. So, for people who are concerned about
\end{abstract}

${ }^{1}$ Selçuk Üniversitesi İletişim Fakültesi, sukrubalci@ selcuk.edu.tr, Orcid ID: http://orcid.org/00000002-0477-0622,

${ }^{2}$ Selçuk Üniversitesi İletişim Fakültesi, kadirgolcu @ selcuk.edu.tr, Orcid ID: http://orcid.org/00000001-7320-6745

${ }^{3}$ Selçuk Üniversitesi Sosyal Bilimler Enstitüsü Gazetecilik Anabilim Dalı, aysearsal@hotmail.com, Orcid ID: http://orcid.org/0000-0002-5724-6752, 
social visibility and who have a sense of self-concealment, social media offers a variety of possibilities. This positive or negative possibility that the social media has provided has also begun to be associated with the life satisfaction of the users. This research has been carried out in order to reveal the relationship between youth social media usage patterns, self-concealment and life satisfaction in the case of university students. Data were collected from 333 participants by field survey method. As a result of the research, there was no relationship between the duration of social media usage and self-concealment and life satisfaction. Trends in self-concealment increase the demand for social media to open accounts with different names and to introduce or reflect themselves differently. Those who do not open accounts with different names in social media have higher life satisfaction levels.

Keywords: Social Media, Self-Concealment, Life Satisfaction, Survey

Paper Type: Research paper

\section{Giriş}

İnsan hayatının her evrensinde etkisi kısa bir zamanda güçlü bir şekilde gösteren yeni iletişim mecrası sosyal medya, yediden yetmişe din, dil ya da 1rk gözetmeksizin herkesi ortak bir platformda toplamayı başarabilen yeni bir mecra olarak karşımıza çıkmaktadır. Sosyal medya, sosyal paylaşım siteleri ya da sosyal paylaşım ağları denilen bu yeni ortamlar; herkesin erişimine açık, kişilerin özel profil oluşturarak birbirleriyle iletişim kurabildikleri ortam olarak 2000'li yılların en önemli gelişmelerinden biri olarak gösterilmektedir (Balcı, 2017: 172-173). Bu gelişmeler doğrultusunda hayatın her anını kuşatan sosyal paylaşım sitelerinin doğru biz düzlemde anlaşılması gerekmektedir. Bu noktada Boyd ve Ellison (2008: 211) sosyal ağ sitelerini, (1) "bir sistem içerisinde kullanıcılarına tamamen açık ya da yarı açık bir profil inşa etmeye, (2) bir bağlantı paylaştığınızda diğer kullanıcıların zaman akışında yer edinmeye ve (3) belirli bir sistem içerisinde kendi bağlantıların ile diğerlerinin yaptıklarını görmeye olanak sağlayan internet odaklı hizmetlerdir" şeklinde tanımlamaktadırlar.

Yeni iletişim ortamlarının bu denli hızlı bir şekilde gelişmesi ve yaygınlaşması, her kesimden insanın bilgi iletişim teknolojilerine olan ilgisinin artmasına neden olurken, özellikle sosyal medyanın gücünü daha da arttırmıştır (Vural ve Bat, 2010: 3349). Sosyal medya, gerçek olmayan bir dünyada sosyal etkileşimlere sahip olma firsatı veren bir mecradır. İnsanlar, sanal ortamlar olarak tanımlanabilecek bu dünyaya, kendi bilgilerini postalamak, fotoğrafları paylaşmak, çıkarlarını belirtmek için bazen gerçek kimlikleriyle, bazen de farklı kimliklerle hareket edebilirler. Bu tür etkileşimler, gençlerin, arkadaş edinme ve arkadaşlarından geri bildirim alma gibi sosyalleşmekle ilgili ihtiyaçlarının karşılanmasına imkan tanımaktadır (Pempek et al.., 2009: 228-229). Sosyal medya aracılığıyla birbirlerinden bağımsız insanlar, ortak dünya görüşü veya amaçları çerçevesinde belirli gruplar oluşturarak daha görünür hale gelirlerken; aynı zaman da yeni bir toplumsallaşma şeklini de ortaya koymaktadırlar.

$\mathrm{Bu}$ haliyle son zamanların bu popüler iletişim ortamı; sosyal etkileşim, paylaşım, işbirliği ve yeni toplumsallaşma şekilleri sunarken (Özgür, 2013: 669); yüz yüze iletişime kıyasla kullanım sorunları (Das ve Sahoo, 2011), yalnızlık (Sheldon, 2008; Ryan ve Xenos, 2011; Sheldon, 2012; Yu et al., 2016), narsisizm (Gülnar et al., 2010; Ryan ve Xenos, 2011), depresyon (Steers et al., 2014; Blachino et al., 2015; Khattak et al., 2017) ve bağımlılık 
(Pelling ve White, 2009; Wilson et al., 2010; Kuss ve Griffiths, 2011; Andreassen et al., 2012; Çam ve İşbulan, 2012; Balc1 ve Gölcü, 2013) gibi olumsuz etkilere de yol açmaktadır.

Sosyal medya; aynı zamanda bireylerin yalnızlık, kabul edilme isteği ve ait olma duygusu gibi psikolojik durumlarına da yeni açlımlar getirmiştir (Vincent, 2016). Bireyler sosyal medya ortamında daha önce hiç tanımadığı ve varlığından haberdar olmadığı herhangi bir kullanıcı ile iletişime geçerek, yeni özgürlük alanları oluşturabilmektedir. Bu ortamda isterse birey kendini gizleyerek, ismini, cinsiyetini, toplumsal rolünü ve statüsünü değiştirebilmektedir.

Kullanımlar ve doyumlar yaklaşımında da vurgulandığı gibi; toplumsal yaşamda bireyler istek ve ihtiyaçlarını karşılamak üzere kitle iletişimini kullanmakta ve tatmin sağlamaktadır (Katz et al., 1973; Katz et al., 1974). Böylece kendini gizleme, yaşam doyumu ve sosyal medya kullanımı birbirleriyle ilişkili konular olarak ön plana çıkmaktadır.

Yeni bir kimlik kazanan ya da var olan kimliğini değiştirme yoluna giderek farklı bir tecrübe yaşayan sosyal medya kullanıcısı ya da yüz yüze iletişimde kendi kimliklerini gizleme imkânına sahip olamayan bireyler; sanal âlemin görünmez yüzlerinin kelimelerle görünür hale geldiği ortamda, kendileri ile zıt özellikler taşıyan kimlikler arkasına gizlenebilmektedir (Akkaş, 2013: 52). Böylece reddedilme korkusu ve utanç duygusuyla ilgili endişeler azalmaktadır (Yu et al., 2015: 240). Bu haliyle sosyal medya, bireylerin sosyalleşme, paylaşım, iletişim gibi birçok konudaki ihtiyaçlarına cevap vermektedir. Öyle ki sosyal medyaya yönelik tutumların ve sosyal medyadaki davranışları etkileyen kişilik özelliklerinin incelenmesi; hem sosyal medyanın iletişim ve sosyalleşmede etkili bir biçimde kullanılması hem de bu konudaki olası zararlarının önüne geçilmesi konusunda önem arz etmektedir (Bozkur ve Gündoğdu, 2017: 150).

Söz konusu önemden yola çıkılarak dizayn edilen bu araştırmada; üniversite öğrencilerinin sosyal medyaya yönelik tutumlarının, kendini gizleme eğilimi ve yaşam doyumu gibi kişilik özellikleriyle ilişkili olup olmadığının incelenmesi amaçlanmıştır. Ayrıca, kendini gizleme ve yaşam doyumu puanlarının, sosyal medyada kendini farklı yansıtma ve sahte hesap kullanma davranışına göre farklılaşıp farklılaşmadığının incelenmesi hedeflenmektedir. Son olarak kendini gizleme eğilimi ile yaşam doyum düzeyi arasındaki ilişki de araştırılmıştır.

\section{Sosyal Medya Kullanımı ve Kendini Gizleme}

Sır, bir bireyin diğerlerinden aktif ve bilinçli bir şekilde sakladığı özel bilgilerden oluşmaktadır (Kelly, 1999: 105). Hemen her insanda kendinde kusurlu gördüğü ya da paylaşmaktan çekindiği tecrübeleri bulunmaktadır. Bu çerçevede birey kendisi hakkında bazı şeyleri, bazen her şeyi paylaşmaktan çekinen bir tavır içerisine girebilir. Yapılan klinik araştırmalar da göz önünde bulundurulduğunda, bazı bireylerin diğerlerine göre kendilerini daha çok gizleme ihtiyacı hissedebilirler. Bu hissin altında cinsel istismar, tecavüz, yas, aile sırrı, kendisiyle ilgili olumsuz düşünceler, kişisel ilişkilerinde mutsuzluk ve ciddi sağlık problemleri gibi birçok acı veren ya da travmatik tecrübe göze çarpmaktadır (Larson ve Chastain, 1990: 439-440). Kelly (1999: 105)'ye göre; bu ac1 verici ya da travmatik kişisel deneyimlerin bekçileri olarak kendilerini gören bireyler, gizlenme yolunu seçerler. Bunun yanında yapılan araştırmalara göre yaşanan bu olayların dışında içinde bulunulan toplumsal 
çevre gibi diğer etkenler de kendini gizleme konusunda belirleyici olmaktadır. Bu bağlamda Quercia ve arkadaşlarının (2012: 306) yaptığı çalışmada; gizliliğin, yalnızca kültürler arasında farklılık göstermeyen, aynı zamanda bireyler arasında farklılık gösteren fikirler ve uygulamalardan oluştuğu ve bu farkl11ıkların yaş, cinsiyet ve internet okuryazarlığ gibi çeşitli faktörlere bağlı olduğu bulunmuştur. Dolayısıyla kendini gizleme, diğer bağlamlarda uyumsuz bir kontrol ve kaçınma odaklı duygu/ davranış düzenleme stratejisi olarak tanımlanabilir (Edmunds et al., 2013: 3).

Kendini gizleme tutumları bir bakıma psikolojik bir ihtiyaç gibi gözükmesinin yanında, ortaya çıkardığı bilişsel ve fiziksel problemler sebebiyle araştırmalara konu olmuştur (Kelly ve Achter 1995; Kelly, 1999; Friedlander et al., 2012; Larson ve Chastin, 1990; Maroko, et al., 2015; Magsamen-Conrad et al., 2014). Yine literatür, sir saklamanın depresyon, anksiyete, yalnızlık gibi psikolojik; fiziksel yakınma, baş ağrısı ve mide bulantısı gibi fizyolojik ve sosyal destek yoksunluğu gibi, psikososyal problemlerle yakından ilişkili olduğunu göstermektedir (Deniz ve Çok, 2010: 426). Aslında kendini gizleme tutumu, kişisel bilginin (düşünceler, duygular, eylemler veya olaylar) bilinçli bir şekilde gizlenmesini ifade etmektedir (Larson et al., 2015: 707). Yüz yüze iletişimde gizlenmek istenen bu bilgiler çoğu zaman başarılı şekilde gizlenemese de yeni iletişim teknolojilerinin sunmuş olduğu olanaklar, bunu mümkün kılmakta ve hatta teşvik etmektedir. Aracılı iletişim şekliyle internet dolayısıyla sosyal medya kullanımı bireylerdeki gizli kalmış duyguları ya da gizlenmek istenenler hakkında birçok seçenek ve kaçış sunmaktadır.

Okur ve Özkul (2015: 220)'a göre; birçok durumda sanal topluluklar, gerçek ve sanal sosyal kimliklere sahip üyelerden oluşmaktadır. Ayrıca sosyal paylaşım siteleri bireylerin alternatif kimlik oluşumunu şiddetlendirebilmektedir. Sanal dünyada alternatif kimlik oluşturmayı seçen bireyler ya hayal ettikleri kimliği ya da gerçek dünyada sosyal olarak daha avantajlı algılanan kişisel kimlikleri tercih etmektedirler. Ayrıca, sanal alanda kimlik, fiziki beden olmadan da var olabilmektedir. Dolayısıyla kişisel kimliklerin sosyal medyadaki yansıması olan sosyal medya profilleri; kendiliğinden olağanüstü pencereler olmanın yanı sıra bilgilerin gizlenmesi ve ifşa edilmesi açısından kimlik yönetiminin bir anahtarıdır (Quercia et al., 2012: 306).

Kendini gizleme; hem kişilik değişeni hem de kişiler arası süreci yansıtan bir durum olarak ortaya konmuştur (Terzi et al., 2010: 646). Dolayısıyla sosyal medya kullanımında önemli bir sorun olarak karşımıza çıkan kendini gizleme bireyin yaşam içindeki tutumlarını ve kalitesini olumsuz etkileyen bir tavırdır. Bireylerin sıkıntı verici bilgiyi saklama düzeyinin durumsal içerikle, sosyal ortamla ve bilginin içeriğine bağl1 olduğu vurgulanmaktadır. Özellikle sosyal yönden tabu olan konuların, kişisel olarak sıkıntı veren bilgilerden daha fazla saklandığ 1 ifade edilmektedir (Vrij et al., 2002; aktaran Terzi et al., 2010: 646). Bu haliyle kendini gizleme, daha içselleştirici problemlerle ilişkilendirilmelidir (Edmunds et al., 2013: 6).

Teknolojinin çifte doğası, hem gizleme hem de açığa çıkarma biçiminde tezahür etmektedir. Bu anlamda internet yüz yüze ve kitle iletişiminde var olan tanımların dışında kendisini konumlamaktadır. Kaynak ve alıcı kavramlarının yerini, kullanıcı yani katılıme almaktadır. Kaynak ve alıcı arasındaki ayrım ortadan kalkmıştır. Kullanıcı mesajın hem yaratıcısı hem de alıcısı konumundadır. Bireylere güvenli bir mekân sağlayan anonimlik, internet üzerinde mesaj kaynağının kendisini gizli kılma eğilimini artırmaktadır (Akkaş, 
2013: 46). Sosyal medya yukarıda da bahsedildiği üzere bireylere kendilerini farklı tanıtabilme özelliğine açık şekilde tasarlanarak sahte hesaplar almalarına ve olduklarından farklı davranmalarına olanak tanımaktadır. Bu bağlamda gerçek dünyada bireyin gündelik yaşamda yapamadıkları, ifade edemedikleri, açığa vurmaktan çekindikleri her türlü durum, tutum ve fikir bilgisayar klavyesinin olanakları içerisinde ifade edilir. Dünya bir bilgisayar ekranına dönüştüğünde özel ve kamusal arasında bir ayrımdan söz etmek olanaksızlaşır. Her şey görülebilir ya da hiçbir şey görünemezdir (Akkaş, 2013: 47).

$\mathrm{Bu}$ çalışmanın konusu ekseninde ele alındığında kendini gizleme; sosyal medya kullanımının doğrudan belirleyicisi olarak değerlendirilmektedir. Sosyal medya vasitasıyla kullanıcılar, gerçek kimliklerini gizleyebilir ve yeni bir tane oluşturabilirler. Yeni bir kimlik yaratmanın bazı nedenleri var. Bunlardan biri mahremiyettir. Sosyal medya kullanıcıları güvenlik sorunları nedeniyle de gerçek kimliklerini gizleme gibi bir çabanın içerisine girebilirler. Aynı zamanda sosyal medya, insanların olmak istedikleri kişi olmasına imkân tanımaktadır. Anonim olmak, sosyal medya ortamında daha rahat ve özgür hareket etme yönündeki motivasyonları da güçlendirmektedir. Kimse gerçek kimliği veya kişinin özelliklerini bilmek zorunda değildir. Bu sayede sosyal medya kullanıcıları istenmeyen, stresli özelliklerini gizleyebilir ve başkalarının benimsediği bir kişi olabilir. Fiziksel görünüm, utangaçlık, düşük benlik saygısı vb. gibi istenmeyen özellikler bu sayede gizlenmiş olmaktadır (Doğan ve Çolak, 2016: 180). Aynı zamanda sosyal medya aracığıyla gerçekleştirilen iletişim, anonimlik duygusunun gelişimini sağlar ve bu durum yüz yüze iletişimden daha az kaygıya neden olur (Rice ve Markey, 2009: 38).

Doğan ve Çolak (2016: 179) tarafından Bolu'daki lise öğrencileri arasından seçilen bir örneklem üzerinde yapılan araştırma; kendini gizlemenin, sosyal medya kullanımının önemli bir belirleyicisi olduğunu göstermiştir. Çalışma bulguları sosyal görünüş kaygısının kendini gizleme ve yalnızlığı etkilediğini göstermiştir. Yine bu araştırma ile sosyal medya kullanımı ile kendini gizleme arasında pozitif yönde anlamlı korelasyon ortaya konmuştur. Diğer bir ifadeyle kendini gizleme düzeyi arttıkça, sosyal medya kullanımında bir artış yaşanmaktadır.

\section{Sosyal Medya Kullanımı ve Yaşam Doyumu}

Bireyler için yaşamdan alınan mutluluk, psikolojik bir tamamlayıcı olma özelliğinin yanında, hayattaki varlığını kuvvetlendirici ve fayda sağlayıcı bir durumu içinde barındırmaktadır. Bu bağlamda öznel iyi-oluş, birbiriyle ilişkili üç bileşenden oluşmaktadır: Olumlu duygulanım, olumsuz duygulanım ve yaşam doyumu. Olumlu ve olumsuz duygulanım, hoşa giden ve gitmeyen duygulardan oluşmakta iken, yaşam doyumu öznel iyi oluş yapısının bilişsel/yargısal boyutunu meydana getirmektedir (Diener et al., 1985: 71).

Bireyin kendi yaşamına ilişkin sahip olduğu genel yarg1 ve değerlendirmeler olarak tanımlanan yaşam doyumu (Çivitçi, 2012: 322); insanların sosyal, iş ve ev hayatı gibi öznel alanlardaki tatmin duygusunun ortaya çıkardığı bir duygu olarak karşımıza çıkmaktadır. Bireylerin bilişsel varoluş sürecinde içinde bulunduğu sosyal ilişkiler ortamından etkilenerek duygusal ve psikolojik durumlar içerisine girmesi ve kendini mutlu olarak tanımlaması bu doyumun temelinde yer almaktadır denilebilir. Sosyal ilişkilere yaklaşma eğilimin artması ve yeni sosyal ilişki kaynaklarının inşa edilmesi, psikolojik iyi oluşun ilişkilerde nitelik ve niceliği arttırma mekanizmaları olarak görülmektedir (Lyubomirsky et al., 2005; aktaran; 
Kermen et al., 2016: 21-22). Dolayısıyla sosyal ilişkiler, yaşam doyumu ile ilişkili önemli bir yaşam alanını temsil etmektedir (Dağlı \& Baysal, 2016: 1251).

Günümüz sosyal ilişkileri incelendiğinde ise karşımıza yüz yüze ilişkiler yerine sanal ilişkiler, sosyal medya üzerinden yürütülen ilişkiler çıkmaktadır. Sosyal paylaşım sitleri bu konuda insanlara birbirinden farklı olanaklar sunan yeni bir iletişim yöntemi olarak ortaya çıkmaktadır. Bu siteler üzerinden kişiler kendi fikirlerini veya beğenileri rahatça paylaşırken aynı zamanda başkalarının hayatları hakkında yüz yüze görüşmeden doğru ya da yanlış olduğunu bilmeden fikir sahibi olmaktadırlar. Son zamanlarda internetin sağlamış olduğu bu olumlu ya da olumsuz olanak yeni bir iletişim ortamı ortaya çıkarırken bireylerin yaşam doyumları ile ilişkilendirilmeye başlamıştır. Buradan hareketle Şahin ve arkadaşlarına (2017: 392) göre; sosyal medya uygulamaları amacından uzaklaşıp saplantı noktasına varan kullanımı sonucunda, bireylerin internette gördükleri ve gerçek hayatlarından çok farklı veya hayali yaşamların etkisinde kalmaları ve kendi yaşamlarından hoşnut olmamaları yani yaşamlarından doyum almamaları söz konusu olabilmektedir.

Yaşam doyumunun sosyal medya kullanımı üzerindeki etkileri ile ilgili literatür incelediğinde, bir uzlaşmanın olmadığı dikkat çekmektedir. Bazı araştırmalar yaşam doyumu ile sosyal medya kullanımı arasında pozitif yönde anlamlı ilişki tespit ederken (Hawi ve Samaha, 2016; Srivastava, 2015; Ractham ve Techatassanasoontorn, 2014); diğer araştırmalarda (Blachnio et al., 2016; Balcı ve Koçak, 2017) sosyal medyanın yaşam doyumu üzerinde negatif etkilere yol açtığı bulgulanmıştır. Yine Whitney ve Kirsten'nin (2012) üniversite öğrencileri üzerinde yürüttüğü araştırmanın bulguları; Facebook'da kendini açma davranışı ile Facebook kullanımından sağlanan doyum arasında anlamlı ilişki olduğunu göstermektedir. Araştırmada Facebook vasıtasıyla kendini daha çok açan üniversite öğrencilerinin, daha fazla doyum elde ettikleri tespit edilmiştir.

Balcı ve Koçak'ın (2017) yaptığı araştırmanın bulguları mercek altına alındığında ise; üniversite öğrencilerinin yaşam doyum düzeyleri internet ve sosyal medya kullanım sıklığı arasında negatif yönde anlamlı ilişki dikkat çekmektedir. Katılımcıların yaşam doyum düzeyleri arttıkça, günlük sosyal medya kullanım sürelerinde bir azalma kendini göstermektedir. Yaşam doyumu düşük olanlar, alışkanlık olduğu için daha sık sosyal medya kullanmaktadırlar. Yine araştırma sorularına cevap verenlerin yaşam doyum düzeyleri arttıkça, boş zamanları değerlendirmek amacıyla sosyal medya kullanım sıklığında bir azalma yaşanmaktadır.

\section{Kendini Gizleme ve Yaşam Doyumu}

Kendini gizleme ve yaşam doyumu arasındaki ilişki, çeşitli dönemlerde yapılan araştırmalarla ortaya konulmuştur. Örneğin Wismeijer ve arkadaşları (2009: 742-744) da araştırmalarında, hem erkek hem de kadınlar için, kendini gizleme ile yaşam doyumu, psikolojik iyi oluş ve öznel sağlık durumu arasında orta derecede negatif korelasyon ortaya koymuşlardır. Bu uyumsuz duygu düzenlemesinde önemli olan, sosyal destek (arama) eksikliğidir. Sosyal desteğin sürekli olarak duyguları, bilişleri ve davranışları etkileyerek öznel iyi oluşu teşvik ettiği bilinmektedir. Bu nedenle, kendini gizleyenler için sosyal desteğin eksikliği, kendini gizleme, duygu durumu düzenleme ve öznel iyi oluş arasındaki olumsuz ilişkide önemli bir unsur olabilmektedir. 
Benzer bir şekilde Uysal ve arkadaşları (2010: 6) kendini gizleme ile yaşam doyumu arasında negatif yönde anlamlı bir ilişki tespit etmişlerdir. Diğer bir ifadeye kendini gizlemenin yaşam doyumu üzerinde olumsuz bir etkisi söz konusudur. Bir diğer araştırmada Uysal ve arkadaşları (2012a: 42), kendini gizlemenin temel ihtiyaçlarla ve ilişki doyumuyla 1lımlı negatif bir ilişki gösterdiğini bulgulamışlardır.

Kendini gizleme tutumu, bireylerde fiziksel ve psikolojik birçok soruna yol açarken; yaşam doyumları üzerinde olumsuz etkiler meydana getirebilmektedir. Öyle ki; MagsamenConrad ve arkadaşları (2014: 28) yaptıkları araştırmada kendini gizlemenin, yaşam doyumunda ve sosyal refahta azalmaya neden olduğunu ortaya koymuşlardır.

Ergenler ve genç yetişkinler üzerinde yapılan araştırmalarda, kendini gizlemenin bireyleri fonksiyonel açıdan sınırladı̆̆ı, sosyal açıdan soyutladığı ve psikolojik sıkıntılara yol açtığı ve psikolojik iyi oluşu azalttığı, yaşam doyumunu düşürdüğü ve depresif semptomları arttırdığı bulunmuştur. Bu nedenle, ergenlerin yaşam doyumu kendini gizleme faktöründen dolayı düşebilir. Ayrıca, kendini gizleme eğilimi içinde olan ergenler, heyecan arayışı aktiviteleri sayesinde, olumsuz yaşantılarını, anksiyete ve olumsuz benlik saygısını ve psikolojik sıkıntılarını tolere edebilirler (Çelik, 2015: 351).

Çelik (2015: 356) yürüttüğü araştırmada, kendini gizlemin yaşam doyumunu düşürdüğü sonucuna ulaşmıştır. Kendini gizleme eğiliminde olan ergenler; sıkıntılarını ve kendileri ile ilgili olumsuz bilgileri (düşünceler, duygular, davranışlar veya olaylar) gizledikleri, diğer bireylere kendilerini açmaktan kaçındıkları ve psikolojik yardım almaya karşı olumsuz direnç gösterdikleri için yaşam doyumları düşebilmektedir.

\section{Araştırmanın Amacı ve Önemi}

$\mathrm{Bu}$ araştırma; üniversite öğrencilerinin sosyal medya kullanım süreçlerinde, kendini gizleme tutumu ve yaşam doyumu üzerine düşünceleri arasındaki ilişkinin boyutlarını ortaya çıkarmak amacıyla tasarlanmıştır. Özellikle sosyal medya kullanım süreçlerinde üniversite öğrencilerinin kendini gizleme davranışları ve yaşam doyumları arasındaki ilişkinin detaylıca açıklanabilmesi adına veriler toplanmıştır.

Literatür incelendiğinde; ergenlerin kendini gizleme eğilimi ve sosyal medya tutumları arasında pozitif yönde anlamlı ilişki olduğu söylenebilmektedir. Sosyal medya kullanımı kendini gizleme eğilimi yüksek olan ergenlerin gerçek yaşamdaki sosyal ortamlardan izole olma durumunu arttırırken; gerçek sosyal ortamlarda gideremedikleri paylaşım ihtiyaçlarını giderdiği ve sosyal anlamda kendilerini daha yetkin algılamalarını sağladığı düşünülmektedir (Bozkur ve Gündoğdu, 2017: 156). Kendini gizleme isteği, sosyal medya kullanımını doğrudan öngörür. Sosyal medya kullanıcıları gerçek kimliklerini gizleyebilir ve yeni bir tane oluşturabilirler. Yeni bir kimlik yaratmanın bazı nedenleri vardır: Bunlardan biri mahremiyettir. Sosyal medya kullanıcıları, güvenlik sorunları nedeniyle de gerçek kimliklerini gizleyebilir. Sosyal medyanın, insanları, olmak istedikleri kişi konumuna getirebilme yönündeki potansiyeli, kendini gizleme yönündeki eğilimleri artırmaktadır Doğan ve Çolak, 2016: 180). Bu olası ilişkiden hareketle 1 numaralı hipotez formüle edilmiştir.

H1. Sosyal medyada farkl1 isimle hesap açma durumuna göre kendini gizleme düzeyi anlamlı farkl1lık gösterir. 
Sosyal medya kullanımı ile yaşam doyumu arasındaki ilişkiyi inceleyen çalışmaların birbirleriyle çelişen sonuçları dikkat çekmektedir. Bazı araştırmalar yaşam doyumunun, sosyal medya kullanımı üzerinde pozitif yönde bir etkiye sahip olduğunu tespit ederken (Hawi ve Samaha, 2016; Srivastava, 2015; Ractham ve Techatassanasoontorn, 2014); diğer araştırmalarda (Blachnio et al., 2016; Balcı ve Koçak, 2017) yaşam doyumu ile sosyal medya kullanımı arasında negatif ilişsinin varlığına dikkat çekilmiştir. Bu tartışmalardan 2 numaralı hipotez ortaya konulmuştur.

H2. Katılımcıların yaşam doyumu, sosyal medyada kullanım süresini negatif yönde etkilemektedir.

Öte yandan kendini gizleme ile yaşam doyumu arasındaki ilişki de yapılan araştırmalarla ortaya konulmuştur. Yapılan araştırmalarda (Wismeijer et al., 2009; Uysal et al., 2010; Uysal et al., 2012a; Magsamen-Conrad et al., 2014; Çelik, 2015) kendini gizlemenin, yaşam doyumunda genelde negatif etkiye yol açtığı üzerinde durulmuştur. Söz konusu bulguları yeniden test etmek amaciyla, 3 numaralı hipotez dizayn edilmiştir.

H3. Katılımcıların sosyal medyada kendini gizleme davranışı ile yaşam doyumu arasında, negatif anlamlı ilişki bulunmaktadır.

\section{Yöntem}

Yöntem olarak saha araştırmasının kullanıldığı bu araştırmada, Selçuk Üniversitesi Alâeddin Keykubat Kampüsü içerisindeki fakülte, yüksekokul ve meslek yüksekokullarında öğrenim gören öğrencilerden sosyal medya kullanımları, kendini gizleme tutumu ve yaşam doyumu üzerine düşüncelerini ögrenmek amacıyla veriler toplanmıştır.

\subsection{Araştırmanın Uygulanması ve Örneklem}

Araştırmanın evrenini; Selçuk Üniversitesi Alâeddin Keykubat Kampüsü içerisindeki fakülte, yüksekokul ve meslek yüksekokullarında öğrenim gören öğrenciler oluşturmaktadır. Selçuk Üniversitesi, farklı bölgelerden gelen ve farklı alt kültürlere sahip seksen binin üzerindeki öğrencisi sayısıyla itibariyle; Türkiye'nin en büyük üniversitelerinden biri konumundadır. Yine Selçuk Üniversitesi, son yıllarda internet teknolojisi alanında gerçekleştirdiği büyük yatırımlarla tüm öğrencilerin internet ve sosyal medya hizmetlerinden yararlanmasını daha da kolaylaştırmıştır (Balcı ve Gülnar, 2009: 11). Çalışmada özellikle üniversite öğrencileri gibi toplumun ergen ve genç yetişkinlerinin seçilmesinin nedeni ise; onların sosyal medya erişimlerinin ve bilgi birikimlerinin daha fazla olması, dolayısıyla diğer nüfus gruplarına kıyasla sosyal medya kullanıcısı olma ihtimallerinin daha yüksek düzeyde bulunmasıdır. Yine sosyal medyada kendini gizleme davranış örüntülerinin; diğer yaş gruplarına (örneğin, yaşlılara) kıyasla ergen ve genç yetişkinlerde daha fazla düzeyde görülebilmesi, çalışmanın üniversite öğrencileri üzerinde odaklanması sonucunu doğurmuştur. Ayrıca ulaşılabilirlik ve araştırma maliyetleri de göz önünde bulundurularak, üniversite öğrencileri üzerinde araştırma dizayn edilmiştir.

Örneklemin belirlenmesinde rastlantısal örneklem tekniği kullanılmıştır. Araştırmaya konu olan veriler, katılımcılarla yüz yüze görüşmeye dayalı anket tekniği ile toplanmıştır. Yapılan incelemenin ardından 333 anketin analize uygun olduğu kararına varılmıştır. 


\subsection{Veri Toplama Araçları}

Üniversite öğrencilerinin sosyal medyaya yönelik tutumlarının, kendini gizleme eğilimi ve yaşam doyumu gibi kişilik özellikleriyle ilişkisini mercek altına alan bu çalışma için 35 soruluk bir anket hazırlanmıştır. Anket formu; bireylerin anlayacağı şekilde konu ile ilgili yapılmış çalışmalar (Larson ve Chastain, 1990; Deniz ve Çok, 2010; Balcı ve Koçak, 2017; Dağl1 ve Baysal; 2016; Bozkur ve Gündoğdu, 2017) örnek alınarak oluşturulmuştur. Anket formunda aşağıda tanımlanan ölçekler yer almaktadır:

Yaşam Doyum Ölçeği (Satisfaction with Life Scale): Yaşam Doyum Ölçeği, Diener, Emmons, Larsen ve Griffin (1985) tarafindan geliştirilen tek faktör ve 5 eşanlamlı maddeden oluşmaktadır. Diner ve arkadaşları (1985) ölçeğin alfa değerini 0,87; Pavot ve arkadaşları (1991: 154) ise 0,83 olarak hesaplamıştır. Son zamanlarda öğretmenler üzerinde ölçeğin Türkçeye uyarlama çalışmalarından birini gerçekleştiren Dağlı ve Baysal (2016: 1259), ölçeğin Türkçe formunun özgün ölçek ile dilsel eşdeğerliğini sağlandığını ifade etmektedir. Araştırma sonucunda, okullarda yaşam doyumunu belirlemek amacıyla kullanılabilecek tek boyutlu toplam 5 maddeden, Likert tipi 5'lik derecelendirmeden oluşan geçerli ve güvenilir bir ölçek üretilmiştir. Ölçeğin Cronbach's Alpha iç tutarlık kat sayısı 0,88 ve test- tekrar test güvenirliği ise 0,97 olarak saptanmıştır. Balcı ve Öğüt (2018) aynı ölçeğin güvenilirliğini 0,84 olarak tespit etmiştir. Bu çalışmada ölçeğin Cronbach's Alpha güvenilirlik değeri 0,77 olarak hesaplanmıştır.

Kendini Gizleme Ölçeği (Self-Concealment Scale): Kendini Gizleme Ölçeği, Larson ve Chastain (1990) tarafından geliştirilmiş; Deniz ve Çok (2010) tarafından da Türkçe'ye uyarlaması yapılmıştır. Bu ölçek; kendine saklama yönelimi, başkalarıyla paylaşılmayan bir sır ya da olumsuz düşüncelere sahip olma ve saklanan kişisel bilginin açıklanmasını ölçen toplam 10 maddeden oluşmaktadır (Deniz ve Çok, 2010: 427). Tek boyutlu ve 5'li likert tipi bu ölçekten alınabilecek en düşük puan 10, en yüksek puan ise 50'dir. Ölçekten alınan puan arttıkça kendini gizleme eğiliminin de artış gösterdiği bilinmektedir. Larson ve Chastain (1990) ölçeğin Cronbach alfa iç tutarlık katsayısını 0,83 olarak bulmuşlardır. Ölçeğin test- tekrar test güvenirlik katsayısı ise 0,81 olarak rapor edilmiştir. Deniz ve Çok (2010)'un araştırmasında ölçeğin Cronbach Alfa değeri 0,85 olarak bulgulanmıştır. Bu araştırmada da ölçeğin güvenilirlik katsayısı 0,85 olarak tespit edilmiştir.

Kişisel Bilgi Formu: Bu kısımda yaş, cinsiyet, ikamet etme biçimi gibi demografik değişkenlerin yanı sıra; katılımcıların sosyal medya kullanımlarına yönelik olarak günlük sosyal medya kullanım süresi, haftalık sosyal medya kullanım sıklığı, sosyal medyada sahte hesap kullanıp kullanmadıkları ve sosyal medyada kendilerini farklı yansitıp yansıtmadıklarına yönelik sorular bulunmaktadır.

\subsection{Verilerin Analizi ve Kullanılan Testler}

Saha araştırması 1-15 Mayıs 2018 tarihleri arasında katılımcılarla yüz yüze görüşme yoluyla gerçekleştirilmiştir. Elde edilen veriler, istatistik programı kullanılarak, bilgisayar ortamında analiz edilmiştir. Verilerin analizinde sırasıyla; katılımcıların demografik özelliklerini saptamak amacıyla Frekans Analizi uygulanmıştır. Kendini gizleme ve yaşam doyumu puanlarının; cinsiyet ile sosyal medyada kendini farklı yansitma ve sahte hesap kullanma davranışına göre farklılaşıp farklılaşmadığını belirlemek amacıyla (Hipotez 1'i test 
etmek için) Bağımsız Örneklem T-Testi kullanılmıştır. Sosyal medya kullanımı ile kendini gizleme ve yaşam doyumu arasındaki ilişkinin düzeyi ve yönünü belirlemek amacıyla da (Hipotez 2 ve Hipotez 3'ü test etmek üzere) Korelasyon Analizi'ne başvurulmuştur.

\section{Bulgular ve Tartışma}

Bu bölümde öncelikle araştırmaya katılan bireylerin demografik özellikleri ve devamında sosyal medya kullanım alışkanlıkları, kendini gizleme tutumları ve yaşam doyum analizleri ve yorumları verilmektedir.

\subsection{Katılımcıların Bazı Özellikleri}

$\rightarrow$ Araştırma kapsamında yüzde 53,2'si erkek, yüzde 46,8'i ise kadınlardan oluşan, toplamda 333 kişiye anket uygulanmıştır. Dolayısıyla çalışma cinsiyet dağılımı birbirine yakın oranlarda gerçekleştirilerek araştırmanın güvenilirliğinin sağlanmasına katkıda bulunulmuştur (Edmunds et al., 2013: 5).

$\rightarrow$ Katılımcıların yaş aralığına bakıldığında en düşük 18, en yükssek 40 yaşındaki üniversite öğrencisiyle görüşüldüğü dikkat çekmektedir. Katılımcıların yaş ortalaması 21,24'tür.

$\rightarrow$ Öğrencilerin ikamet şekillerine bakıldığında; yüzde 52,9'unun yurtta, yüzde 26,4'ünün ailesiyle ve yüzde 16,5 'inin ise arkadaşlarıyla evde kaldığ görülmektedir. Sonuçlar, yurtta ikamet eden öğrencilerin çoğunluğu oluşturduğunu göstermektedir.

$\rightarrow$ Araştırmaya katılanların yaşam doyumlarının betimleyici istatistikleri incelendiği; en düşük 5, en yüksek 25 puana sahip oldukları dikkat çekmektedir. Katılımcıların yaşam

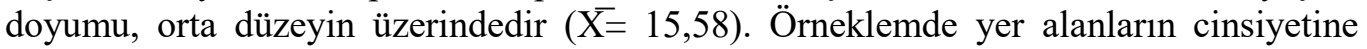
göre yaşam doyum düzeyleri anlaml1 farklılık göstermektedir $(t=-2,07 ; p<0,05)$. Betimleyici istatistik sonuçları; kadınların $(\overline{\mathrm{X}}=16,03)$ yaşam doyum düzeylerinin, erkeklerden $(\overline{\mathrm{X}}=15,19)$ daha yüksek olduğunu ortaya koymaktadır.

$\rightarrow \mathrm{Bu}$ araştırma ile katılımcıların kendine gizleme ölçeğindeki maddelere toplamda en düşük 10, en yüksek 50 puan verdikleri dikkat bulgulanmıştır. Araştırma sorularına cevap verenlerin kendini gizleme düzeylerinin ortalaması $\bar{X}=27,25$ 'dir. Örneklemde yer alanların cinsiyetine göre, kendini gizleme düzeyleri anlamlı farklılık taşımaktadır $(\mathrm{t}=$ $2,78 ; \mathrm{p}<0,01)$. Kendini gözleme düzeyi açısından erkekler $(\overline{\mathrm{X}}=28,42)$; kadınlara $(\overline{\mathrm{X}}=$ $25,92)$ nazaran daha yüksek puanlara sahiptir.

\subsection{Sosyal Medya Kullanım Alışkanlıkları}

Çalışmaya katılan bireylerin sosyal medya kullanım sürelerinin sorulduğu soru neticesinden birbirinden farklı cevaplar alınmasının yanında tabloda değerlendirildiğinde; günlük en az 25 dakika, en çok ise 900 dakika sosyal medya kullandıkları görülmektedir. Bunun yanında katılımcıların günde ortalama 253,56 dakika sosyal medya kullandıkları belirlenmiştir (Bkz. Tablo 1). 
Tablo 1. Katılımcıların sosyal medya kullanım süresinin betimleyici istatistikleri

\begin{tabular}{cccccc}
\hline & N & En Az & En Çok & $\overline{\mathbf{X}}$ & SD \\
\hline Kullanım Süresi & 307 & $25 \mathrm{dk}$. & $900 \mathrm{dk}$. & $253,56 \mathrm{dk}$. & 194,98 \\
\hline
\end{tabular}

Katılımcıların cinsiyetine göre, günlük sosyal kullanım süreleri anlamlı farklılık göstermektedir. Betimleyici istatistik sonuçları; kadınların $(\overline{\mathrm{X}}=286,70)$, erkeklere $(\overline{\mathrm{X}}=$ $225,41)$ oranla, günlük sosyal medya ile daha uzun süre geçirdiklerine işaret etmektedir.

Katılımcıların yüzde 78,1'i sosyal medyayı her gün düzenli kullanırken; yüzde 14 , 2'si haftada 5-6 gün sosyal medya ile zaman geçirmektedir. Haftada 3-4 gün kullananların yüzdesi 5,5 olarak tespit edilirken, yüzde 2,3'lük oranla haftada 1-2 gün kullanım dikkat çekmektedir. Bu bağlamda değerlendirildiğinde; üniversite öğrencilerinin yarıdan fazlası her gün sosyal medya kullanmaktayken; haftada bir iki gün kullanımın oldukça az oranlarda kaldığı görülmektedir.

Tablo 2. Katılımcıların sosyal medya hesapları hakkında bazı istatistikler

\begin{tabular}{lcc}
\hline & Evet (\%) & Hayır (\%) \\
\hline Sosyal medyada farklı bir isimle hesap açtınız mı? & $115(34,7)$ & $216(65,3)$ \\
\hline Sosyal medya hesabınızda gerçek isminizi mi kullanıyorsunuz? & $305(92,1)$ & $26(7,9)$ \\
\hline Sosyal medyada kendinizi farklı tanıttı̆̆ınız ya da yansıttı̆̆ınız oldu mu? & $61(18,4)$ & $270(81,6)$ \\
\hline
\end{tabular}

Tablo 2'ye göre; "sosyal medya da farklı bir isimle hesap açtı̆̆ını" belirtenler yüzde 34,7; açmadıklarını belirtenler ise yüzde 65,3'lük orana sahiptir. "Sosyal medya hesabınızda gerçek isminizi mi kullanıyorsunuz?" sorusuna ise katılımcıların yüzde 92,1'i evet yanıtını verirken; yüzde 7,9'u hayır cevabını vermiştir. Son olarak "sosyal medyada kendinizi farklı tanıttı̆̆ınız ya da yansıttı̆̆ınız oldu mu?" şeklindeki soruyu, örneklemde yer alanların yüzde 18,4'ü evet, yüzde 81,6'sı ise hayır şeklinde yanıtladığı görülmektedir. Genel olarak değerlendirildiğinde; sorulara verilen cevaplarda yüksek oranda gerçek kimlik kullanıldığ vurgulanırken, farklı hesap ve isim kullananların da bulunduğu dikkat çekicidir.

\subsection{Sosyal Medya Kullanımı ile Kendini Gizleme Arasındaki İlişki}

Günlük sosyal medya kullanım süresi ile kendini gizleme düzeyi arasındaki ilişkinin gücü ve yönünü belirlemek açısından Korelasyon Analizi sonuçları incelendiğinde iki değişken arasında anlamlı ilişkinin olmadığı dikkat çekmektedir $(r=0,061 ; \mathrm{p}>0,05)$. (Bkz. Tablo 3).

Tablo 3. Sosyal medya kullanım süresi ile kendini gizleme arasındaki ilişki

\begin{tabular}{cc}
\hline & Kendini Gizleme \\
\hline Sosyal Medya Kullanım Süresi & 0,061 \\
\hline Örneklemde yer alan insanların sosyal medyada farklı isimle hesap açma \\
durumlarına göre kendini gizleme düzeyleri anlamlı farkl1lık göstermektedir $(\mathrm{t}=2,68 ; \mathrm{p}<$ \\
$0,01)$. Betimleyici istatistik sonuçları incelendiğinde; sosyal medyada farklı isimle hesap \\
açanların kendini gizleme düzeyleri $(\overline{\mathrm{X}}=28,86)$, hesap açmayan katılımcılara $(\overline{\mathrm{X}}=26,34)$
\end{tabular}


göre daha yüksektir. Diğer bir ifadeyle, sosyal medyada farklı isimle hesap açma, kendini gizleme yönündeki eğilimleri artırmaktadır (Bkz. Tablo 4). Bu sonuçlarla Hipotez 1 doğrulanmıştır.

Tablo 4. Farklı isimle hesap açma durumuna göre kendini gizleme düzeyindeki farkl1lık

\begin{tabular}{lccccc}
\hline & Farklı İsimle Hesap Açma & $\mathbf{N}$ & $\overline{\mathbf{X}}$ & t-value & Sig. \\
\hline \multirow{2}{*}{ Kendini Gizleme } & Evet & 115 & 28,86 & 2,68 & $\mathbf{0 , 0 0 8}$ \\
& Havir & 216 & 2634 & & \\
\hline
\end{tabular}

Katılımcıların sosyal medya hesabında gerçek isimlerini kullanma durumlarına göre kendini gizleme düzeylerinin anlamlı farklılık taşıdığı, bu araştırma ile bulgulanmıştır $(\mathrm{t}=$ $3,45 ; \mathrm{p}<, 01)$. Analiz sonuçları; sosyal medya hesabında gerçek ismini kullanmayanların $(\overline{\mathrm{X}}=$ $32,50)$, kullananlara $(\bar{X}=26,78)$ nazaran kendini gizleme düzeylerinin daha yüksek olduğunu göstermektedir (Bkz. Tablo 5).

Tablo 5. Sosyal medyada hesabında gerçek ismi kullanma durumuna göre kendini gizleme düzeyindeki farkl11ık

\begin{tabular}{lccccc}
\hline & Gerçek İsmi Kullanma & $\mathbf{N}$ & $\overline{\mathbf{X}}$ & t-value & Sig. \\
\hline \multirow{2}{*}{ Kendini Gizleme } & Evet & 305 & 26,78 & $-3,45$ & $\mathbf{0 , 0 0 1}$ \\
& & & & & \\
\hline
\end{tabular}

Yine benzer şekilde katılımcıların sosyal medyada kendini farklı tanıtma ya da yansıtma durumuna göre, kendini gizleme düzeyi anlamlı olarak farklılaşmaktadır $(\mathrm{t}=2,54$; $\mathrm{p}<0,05)$. Betimleyici istatistik sonuçları mercek altına alındığında; sosyal medya ortamında kendini farklı şekilde tanıtan/ yansıtanların $(\bar{X}=29,63)$ kendini gizleme düzeyleri, yansitmayanlara $(\bar{X}=26,69)$ göre daha yüksektir (Bkz. Tablo 6).

Tablo 6. Sosyal medyada kendini farklı tanıtma/ yansıtma durumuna göre kendini gizleme düzeyindeki farklılık

\begin{tabular}{lccccc}
\hline & Farklı Tanitma/Yansitma & $\mathbf{N}$ & $\overline{\mathbf{X}}$ & t-value & Sig. \\
\hline \multirow{2}{*}{ Kendini Gizleme } & Evet & 61 & 29,63 & 2,54 & $\mathbf{0 , 0 1 1}$ \\
& Havir & 270 & 2669 & & \\
\hline
\end{tabular}

\subsection{Sosyal Medya Kullanımı ile Yaşam Doyumu Arasındaki İlişki}

Araştırmanın bu bölümünde günlük sosyal medya kullanım süresi ile yaşam doyumu düzeyi arasındaki ilişki incelenmiş; Korelasyon Analizi sonuçları iki değişken arasında anlamlı ilişkinin olmadığını ortaya koymuştur ( $r=0,040 ; \mathrm{p}>0,05)$. (Bkz. Tablo 7). Bu sonuçlarla Hipotez 2 reddedilmiştir. 
Tablo 7. Sosyal medya kullanım süresi ile yaşam doyumu arasındaki ilişki

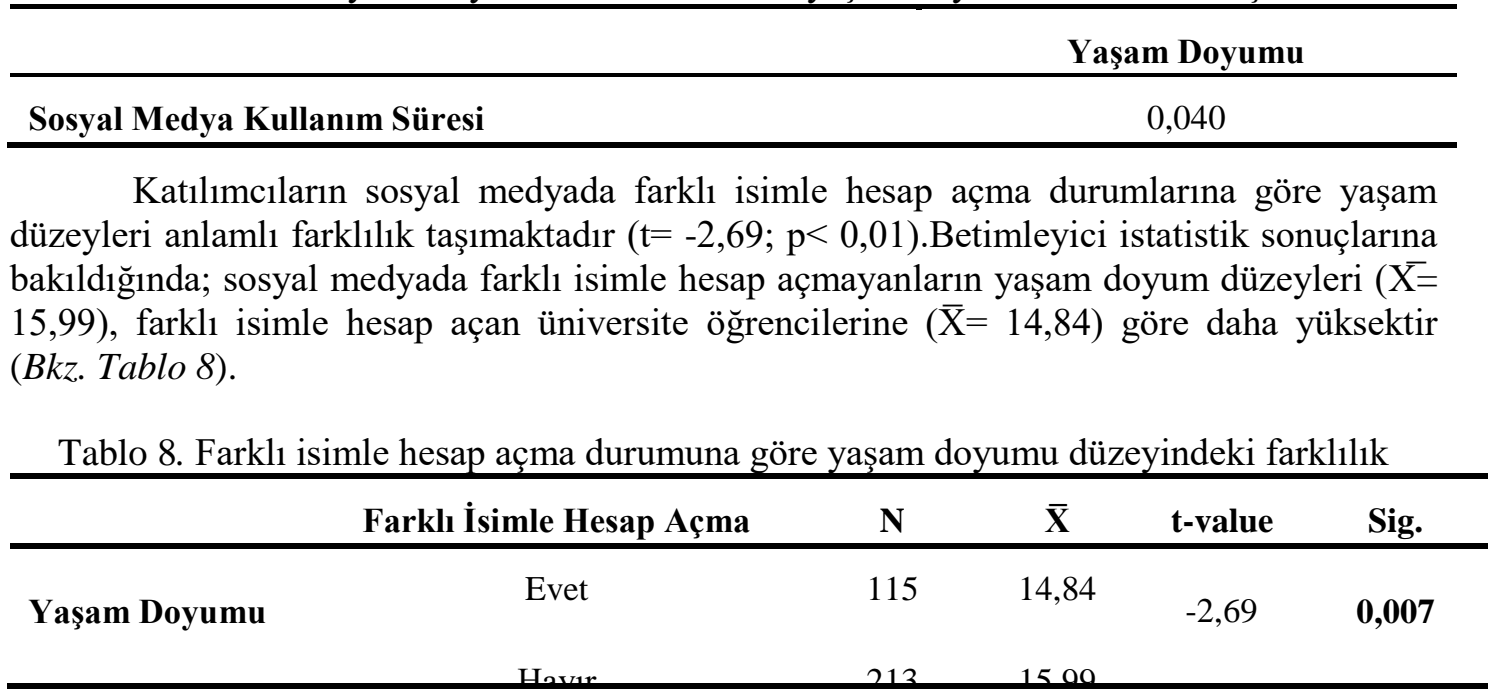

Öte yandan araştırma sorularına cevap verenlerin sosyal medya hesabında gerçek ismini kullanma $(\mathrm{t}=1,67 ; \mathrm{p}>0,05)$ ve sosyal medyada kendini farklı tanıtma/ yansitma durumları $(\mathrm{t}=-1,76 ; \mathrm{p}>0,05)$ ile yaşam doyumları arasında anlamlı ilişki tespit edilememiştir.

\subsection{Kendini Gizleme ile Yaşam Doyumu Arasındaki İlişki}

$\mathrm{Bu}$ araştırmada kendini gizleme düzeyi ile yaşam doyumu arasında, negatif yönde orta düzeyde anlamlı bir ilişki $(r=-0,359, \quad \mathrm{p}<0,01)$ ortaya çıkmıştır. Dolayısıyla katılımcıların sosyal medyada kendini gizleme düzeyleri arttıkça, yaşam doyum düzeyleri azalmaktadır. Bu sonuçlar, Hipotez 3 'ün doğrulandığını göstermektedir.

Tablo 9. Katılımcıların kendini gizleme düzeyleri ve yaşam doyumu arasındaki ilişki

\begin{tabular}{lc}
\hline & Yaşam Doyumu \\
\hline Kendini Gizleme & $-0,359^{* *}$ \\
\hline
\end{tabular}

Not: $* * p<0.01$

Bir başka ifadeyle, sosyal medyada kendini gizleme eğiliminin artması, yaşam doyum düzeyinde bir azalmayı ortaya çıkarmaktadır. Yapılan diğer bazı araştırmalarda (Uysal et al., 2010; Çelik, 2015) da benzer bulguların ortaya çıktığı dikkat çekmektedir. 


\section{Sonuç ve Öneriler}

Bugün, özellikle gençlerin çoğu, yaşıtlarıyla temas halinde kalmak için farklı sosyal medya araçlarını kullanmaktadırlar. Sosyal medya, sosyal iletişimin ötesinde bir süper-lider olarak, sosyal etkileşim için yeni avantajlar sunmaktadır. Sosyal medya kullanımının en önemli avantajlardan biri, farklı insan grupları arasında bilginin çevrimiçi olarak paylaşılmasıdır. $\mathrm{Bu}$ çevrimiçi bilgi paylaşımı, özellikle gençler arasındaki iletişim becerilerinin artmasını da teşvik etmektedir. Sosyal medya araçları, uzak yerlerde yaşayan insanlara ortak bir platformda bir araya getirebilmektedir (Baruah, 2012: 1). Yine Kat1lim ve sosyalleşmede önemli etkilere sahip olan sosyal medya; sanal kimlikler ya da maskeler yoluyla kişinin kendini gizlemesi için de elverişli bir zemin oluşturmaktadır.

İşte bu araştırmada Selçuk Üniversitesi'nden seçilen bir örneklem üzerinde, sosyal medya kullanım örüntüleri ile kendini gizleme ve yaşam doyumu arasındaki ilişki mercek altına alınmıştır. Araştırma kapsamında öncelikle sosyal medya kullanım alışkanlıkları incelenmiştir. Araştırma bulguları; üniversite öğrencileri gibi toplumun genç kesiminin sosyal medyayı yoğun bir şekilde kullandığına işaret etmektedir. Üniversite öğrencileri, günlük yaklaşık dört saatlik bir zamanı sosyal medya karşısında geçirmektedir. Mobil teknolojilerin, günün her saatinde ve her yerden sosyal medyaya bağlanma imkânını sağladığı günümüzde, böyle bir sonucun ortaya çıkması gayet doğal gözükmektedir. Araştırmada kadınların, erkeklere göre günlük daha uzun süre sosyal medya kullandıkları ortaya çıkmıştır. Araştırma sorularına cevap veren öğrenciler, yüksek oranda, sosyal medyada gerçek kimlik kullanıldığı vurgularken; gerçek ismini kullanmayanların oranı yaklaşık yüzde 8 , sosyal medyada kendini farklı tanıtanların oranı ise yüzde $18,4^{\prime}$ tür.

Araştırmaya katılan üniversite öğrencilerinin yaşam doyumlarının orta düzeyin biraz üzerinde olduğu, bu araştırma ile bulgulanmıştır. Cinsiyete göre değerlendirme yaptığımızda; kadınların yaşam doyum düzeylerinin, erkeklerden daha yüksek olduğu dikkat çekmektedir.

Yine araştırma sonucunda üniversite gençliğinin kendini gizleme düzeylerinin çok da yüksek olmadığı belirlenmiştir. Sosyal medyada kendini gizleme düzeyi bakımından, erkeklerin oranı kadınlara göre daha yüksektir. Diğer bir ifadeyle, kadınlar, sosyal medyada gerçek kimliklerini ortaya koymada daha cesaretli davranmaktadırlar.

Sosyal medyada farklı isimle hesap açanların ve kendini farklı şekilde tanıtanların kendini gizleme düzeyleri daha yüksektir. Bu sonuçlar; Bozkur ve Gündoğdu'nun (2017: 155) elde ettiği bulgularla tutarlılık taşımaktadır. Sosyal medya; yalnızlık hissi yaşayan bireye, kendini farklı yansıtma özgürlügü sunmaktadır. Yüz yüze iletişimin bireylerin isteğine bağlı olduğu bu ortam, olmak istenilen ya da farklı yansıtılan kimliklere açı haldedir. Benzer değerlendirmede bulunan Demircioğlu (2015: 160), tüm iletişim sürecine egemen olan bu yeni süreci yeni bir maskelenme yöntemi olarak tanımlarken; aynı zamanda sanal ortamın, somut olarak insanların dış görünüşlerini değiştirmeden ya da farklı kılıklara bürünmelerine gerek duymadan, sanal maskeleriyle değişimin ve gizliliğinin cazibesine elverişli bir zemin hazırlamakta olduğunun altını çizmektedir.

Öte yandan kendini gizleme tutumu ile yaşam doyumu arasında negatif yönde bir ilişki olduğu, bu araştırmanın ulaştı̆̆ bir başka sonuçtur. Araştırmanın bu bulgusunun da daha önceki yapılan araştırma sonuçlarıyla (Uysal et al., 2010; Uysal et al., 2012a; Uysal et 
al., 2012b; Çelik, 2015) tutarlılık gösterdiği görülmektedir. Yaşam doyumu düşük olan bireylerin daha fazla sosyal izolasyon, sosyal ve duygusal yalnızlık yaşadıkları düşünülebilir. Bu bireyler çoğunlukla yalnız kaldıkları için sosyal destek alamamakta ve daha fazla kendini gizleme eğilimi göstermektedirler (Çelik, 2015: 357). Çalışmanın literatür taraması bölümünde ele alındığı gibi; geçmişte yaşanan bazı olay ya da durumları başkasına anlatmamak gibi bir çabayı gerektiren, utangaçlık veya çevrenin baskısıyla belirginleşen kendini gizleme tutumu, bireyler için gereğinden fazla sorumluluk gerektirir. Dolayısıyla bu durum, bireylerin yaşam doyumları üzerine negatif etki oluşturabilmektedir.

Sonuç olarak bu araştırmada; bireylere kendini gizleme tutumu adına yeni bir davranış geliştirme zemini sunan sosyal medyanın rolü ve etkileri konusunda sınırlı bir veri sunmaktadır. Bu açıdan kendini gizleme tutumunun aktif olarak kullanılabildiği sosyal medya ortamının, zamanla yeni çalışmalara konu olması kaçınılmazdır. Gelecekte Türkiye'de dizayn edilecek araştırmalarda, kendi gizleme tutumu ile yalnızlık, utangaçlık, sosyal medya bağımlılığı ve sosyal medya motivasyonları arasındaki ilişki incelenebilir. Bu araştırmada bir bütün olarak sosyal medya kullanımı üzerinden inceleme yapılmıştır. Bundan sonraki araştırmalar; Facebook, Twitter, Swarm, Instagram, WhatsApp vb. gibi her bir aracin kullanımı ile kendini gizleme arasındaki ilişkiye odaklanabilir. Yine ülkenin farklı bölgelerinde farklı örneklemler üzerinde yapılacak araştırmalar; literatürün zenginleşmesi ve karşılaştırmaların yapılması açısından önem taşımaktadır.

\section{Kaynakça}

Akkaş, İ. (2013). Çok Yüzlü İlişkiler Ağında Kimlikler Ve Sanal Cemaatler. Düzce Üniversitesi Sosyal Bilimler Enstitüsü Dergisi, 3 (2), 37-53.

Andreassen, C. S. et al. (2012). Development of a Facebook Addiction Scale. Psychological Reports, 110 (2), 501-517.

Balc1, E. V. (2017). Kültürel Farklllkklar Ekseninde Internet ve Haber. Konya: Litaratürk Yayınları.

Balc1, Ş. \& Gölcü, A. (2013). Facebook Addiction among University Students: "Selcuk University Example". Journal of Studies Turkology, 34, 255-278.

Balc1, Ş. \& Gülnar, B. (2009).Üniversite Öğrencileri Arasında İnternet Bağımlılığı ve İnternet Bağımlılarının Profili. Selçuk İletişim, 6 (1), 5-22.

Balcı, Ş. \& Koçak, M. C. (2017). Sosyal Medya Kullanımı İle Yaşam Doyumu Arasındaki İlişki: Üniversite Öğrencileri Üzerinde Bir Araştırma, 1. Uluslararası İletişimde Yeni Yönelimler Konferansı, Ankara: Nobel Akademik Yayınc1lık, 34-45.

Balcı, Ş. \& Ögüut, N. (2018). Kültürlerarası Etkililik Düzeyinin Bazı Belirleyicileri: "Konya Örneğinde Saha Araştırması". Uluslararası Sosyal Araştırmalar Dergisi, 11 (57), 498509.

Baruah, T. D. (2012). Effectiveness of Social Media as a tool of communication and its potential for technology enabled connections: A micro-level study. International Journal of Scientific and Research Publications, 2 (5), 1-10.

Blachino, A., Przepiorka, A. \& Pantic, I. (2015). Internet Use, Facebook Intrusion, and Depression: Results of a Cross-Sectional Study. European Pyschiatry, 30, 681-684.

Blachnio, A., Przepiorka, A. \& Pantic, I. (2016). Association between Facebook Addiction, Self-Esteem and Life Satisfaction: A Cross-Sectional Study. Computers in Human Behavior, 55: 701-705.

Boyd, D. M. \& Ellison, N. B. (2008). Social Network Sites: Definition, History, and Scholarship. Journal of Computer-Mediated Communication, 13, 210-230. 
Bozkur, B. \& Gündoğdu, M. (2017). Ergenlerde Utangaçlik, Kendini Gizleme Ve Sosyal Medya Tutumları İlişkisi. Mustafa Kemal Üniversitesi Sosyal Bilimler Üniversitesi Dergisi, 14 (37), 147-159

Çam, E. \& İşbulan, O. (2012). A New Addiction for Teacher Candidates: Social Networks. TOJET: The Turkish Online Journal of Educational Technology, 11 (3), 14-19.

Çelik, E. (2015). Kendini Gizleme ve Yaşam Doyumu Arasındaki İlişkide Heyecan Arayışının Aracılık ve Moderatör Rolü. Eğitim ve Bilim Dergisi, 40 (181), 349-361.

Çivitçi, A. (2012). Üniversite Öğrencilerinde Genel Yaşam Doyumu Ve Psikolojik İhtiyaçlar Arasındaki İlişkiler, Çukurova Üniversitesi Sosyal Bilimler Enstitüsü Dergisi, 21 (2), 321-336.

Dağl1, A. \& Baysal, N. (2016). Yaşam Doyumu Ölçeğinin Türkçe’ye Uyarlanması: Geçerlik Ve Güvenirlik Çalışması. Elektronik Sosyal Bilimler Dergisi, 15 (59), 1250-1262.

Das, B. \& Sahoo, J. S. (2011). Social Networking Sites-A Critical Analysis of Its Impact on Personal and Social Life. International Journal of Business and Social Science, 2 (14), 222-228.

Demircioğlu, Z. (2015). İletişim Sürecinde Amaç Ve Niyeti Farklılaştıran Egemen Bir Öğe Olarak Maske. Atatürk İletişim Dergisi, 8, 157-182.

Deniz, M. \& Çok, F. (2010). Psychometric properties and adaptation of the SelfConcealment Scale to the Turkish Adolescents. Elementary Education Online, 9 (1), 424432.

Diener, E., Emmons, R. A., Larsen, R. J., \& Griffin, S. (1985). The Satisfaction with Life Scale. Journal of Personality Assessment, 49, 71-75.

Doğan, U. \& Çolak, T. S. (2016). Self-concealment, Social Network Sites Usage, Social Appearance Anxiety, Loneliness of High School Students: A Model Testing. Journal of Education and Training Studies, 4 (6), 176-183.

Edmunds, J., Masuda, A., Tully, E. C. (2013). Relations among Self-Concealment, Mindfulness, and Internalizing Problems. Georgia State University Psychology Faculty Publication, context=psych_facpub, 1-21.

Friedlander, A., Nazem, S., Fiske, A., Nadorff, M. R. ve Smith, M. D. (2012). Selfconcealment and suicidal behaviors. Suicide and Life. Threatening Behavior, 42 (3), $332-$ 340 .

Gülnar, B.; Balcı, Ş, \& Çakır, V. (2010). Motivations of Facebook, YouTube and Similar Web Services Users Based on Spectacle Performance Paradigm and Diffused Audience, bilig Journal of Social Sciences of the Turkish World, 54, 161-184.

Hawi, N. S. \& Samaha, M. (2016). The Relations among Social Media Addiction, SelfEsteem, and Life Satisfaction in University Students, Social Science Computer Review, August 10: 1-10.

Katz, E.; Blumler, J. G. \& Gurevitch, M. (1974). Uses and Gratifications Research. Public Opinion Quarterly, 37 (4), 509-523.

Katz, E.; Gurevitch, M. \& Hass, H. (1973). On The Use of Mass Media for Important Things. American Sociological Review, 38 (2), 164-181.

Kelly, A. E. \& Achter, J. A. (1995). Self-concealment and Attitudes toward Counseling in University Students. Journal of Counseling Psychology, 42 (1), 40-46.

Kelly, A. E. (1999). Revealing Personal Secrets. Current Directions In Psychological Science, 8 (4), 105-109. 
Kermen, U., Tosun, N. İ. ve Doğan U. (2016). Yaşam Doyumu ve Psikolojik İyi Oluşun Yordayı1cısı Olarak Sosyal Kaygı. Eğitim Kuram ve Uygulama Araştırmaları Dergisi, 2 (2), 1-29.

Khattak, F. A., Ahmad, S. \& Mohammad, H. (2017). Facebook Addiction and Depression: A Comparative Study of Gender Differences. PUTAJ- Humanities and Social Sciences. 25 (1-2), 55-62.

Kuss, D. J. \& Griffiths, M. D. (2011). Online Social Networking and Addiction- A Review of the Psychological Literature. International Journal of Environmental Research and Public Health, 8, 3528-3552.

Larson, D. G. \& Chastain, R. L. (1990). Self- concealment: Conceptualization, measurement and health implications. Journal of Social and Clinical Psychology, 9 (4), 439-455.

Larson, D. G., Chastain, R. L., William T. H. \& Ayzenberg, R. (2015). Self-Concealment: Integrative Review and Working Model. Journal of Social and Psychology, 38 (4), 705 774.

Magsamen-Conrad, K., Verhoff, C. B. \& Greene, K. (2014). Technology Addiction's Contribution to Mental Wellbeing: The Positive Effect Online Social Capital. Computers in Human Behavior, 40, 23-30.

Maroko, M. G., Nymugaro, N.C. \& Gathoni, N. J. (2015). Relationship Between SelfConcealment and Attitudes Toward Seeking Voluntary Counseling and Testing among Students: A Case of Kenyatta University, International Journal of Liberal Arts and Social Science, 3 (2), 8-14.

Okur, H. D. \& Özkul, M. (2015). Modern İletişiminin Arayüzü: Sanal İletişim Sosyal Paylaşım Sitelerinin Toplumsal İlişki Kurma Biçimlerine Etkisi (Facebook Örneği), Süleyman Demirel Üniversitesi Sosyal Bilimler Enstitüsü Dergisi, 21, 213-246.

Özgür, H. (2013). Analyzing the Relationship between Social Networking Addiction, Interaction Anxiousness and Level s of Loneliness of Pre-service Teachers. International Journal of Human Sciences, 10 (2), 667-690.

Pavot, W. G., Diener, E., Colvin, C. R., \& Sandvik, E. (1991). Further validation of the Satisfaction with Life Scale: Evidence for the cross-method convergence of well-being measures. Journal of Personality Assessment, 57, 149-161.

Pelling, E. L., \& White, K. M. (2009). The theory of planned behavior applied to young people's use of social networking web sites. CyberPsychology \& Behavior, 12 (6), 755759.

Pempek, T. A., Yermolayeva, Y. A., \& Calvert, S. L. (2009). College students' social networking experiences on Facebook. Journal of Applied Developmental Psychology, 30 (3), 227-238.

Quercia, D. et al. (2012). Facebook and Privacy: The Balancing Act of Personality, Gender, and Relationship Currency, Proceedings of the Sixth International AAAI Conference on Weblogs and Social Media, 306-313.

Ractham, P. \& Techatassanasoontorn, A. (2014). Social Media Use and Senior Citizen's Life Satisfaction. 25th Australasian Conference on Information Systems, 8th -10th Dec 2014, Auckland, New Zealand.

Rice, L. \& Markey, P. M. (2009). The role of extraversion and neuroticism in influencing anxiety following computer-mediated interactions. Personality and Individual Differences, 46 (1), 35-39.

Ryan, T. \& Xenos, S. (2011). Who uses Facebook? An Investigation into the Relationship between the Big Five, Shyness, Narcissism, Loneliness, and Facebook Usage. Computers in Human Behavior, 27, 1658-1664. 
Sheldon P. (2012). Profiling the Non-users: Examination of Life-position Indicators, Sensation Seeking, Shyness, and Loneliness among Users and Non-users of Social Network Sites. Computers in Human Behavior, 28, 1960-1965.

Sheldon, P. (2008). The Relationship between Unwillingness-to-Communicate and Students' Facebook Use. Journal of Media Psychology, 20, 67-75.

Srivastava, A. (2015). The Effect of Facebook Use on Life Satisfaction and Subjective Happiness of College Students. The International Journal of Indian Psychology, 2 (4): 204-216.

Steers, M. N.; Wickham, R. E., \& Acitelli, L. K. (2014). Seeing Everyone Else's Highlight Reels: How Facebook Usage is Linked To Depressive Symptoms. Journal of Socail and Clinical Pyschology, 33 (8), 701-731.

Şahin, A., Özdemir, A. \& Özgüner, M. (2017). Mobil Uygulama Kabul Düzeyinin Yaşam Doyumuna Etkisi. Sosyal Bilimler Dergisi, 4 (17), 380-394.

Terzi, Ş., Güngör, H. C. \& Erdayı, G. S. (2010). Kendini Saklama Ölçeğinin Uyarlanması: Geçerlik ve Güvenirlik Çalışması. Türk Ĕ̈itim Bilimleri Dergisi, 8 (3), 645-660.

Uysal, A., Lin, H. L. \& Bush, A. L. (2012b). The reciprocal cycle of self-concealment and trust in romantic relationships. European Journal of Social Psychology, 42, 844-851.

Uysal, A., Lin, H. L. \& Knee, C. R. (2010). The role of need satisfaction in self-concealment and wellbeing, Personality and Social Psychology Bulletin, 36 (2), 187-199.

Uysal, A., Lin, H. L., Knee, C. R. \& Bush, A. L. (2012a). The association between selfconcealment from one's partner and relationship well-being. Personality and Social Psychology Bulletin, 38 (1), 39-51.

Vincent, E. A. (2016). Social Media as an Avenue to Achieving Sense of Belonging Among College Students., Vistas Online, https://www.counseling.org/docs/defaultsource/vistas/social-media-as-an-avenue.pdf?sfvrsn=f684492c_8 (Erişim: 1 Temmuz 2018).

Vural, Z. B. A. \& Bat, M. (2010). Yeni Bir İletişim Ortamı Olarak Sosyal Medya: Ege Üniversitesi İletişim Fakültesine Yönelik Bir Araştırma, Journal of Yaşar University, 20 (5), 3348-3382.

Whitney, P. S. \& Kirsten, E. L. B. (2012). Self-disclosure and student satisfaction with Facebook. Computers in Human Behaviour, 28, 624-630.

Wilson, K., Fornasier, S. \& White, K. (2010). Psychological Predictors of Young Adults' Use of Social Networking Sites. CyberPsychology, Behavior \& Social Networking, 13 (2), 173-177.

Wismeijer, A. A. J., van Assen, Marcel A. L. M., Sijtsma, K., \& Vingerhoets, A. J. J. M. (2009). Is the negative association between self-concealment and subjective well-being mediated by mood awareness?. Journal of Social and Clinical Psychology, 28 (6), 728748.

Yu, J., Hu, P. J.-H. \& Cheng, T.-H. (2015). Role of Affect in Self-Disclosure on Social Network Websites: A Test of Two Competing Models. Journal of Management Information Systems, 32 (2), 239-277.

Yu, S., \& Wu, A. M. S., \& Pesigan, I. J. A. (2016). Cognitive and Psychosocial Health Risk Factors of Social Networking Addiction. International Journal of Mental Health and Addiction, 14 (4), 550-564. 